\title{
COVID-19 pandemisinde cinsellik ve cinsel sağlık
}

\section{Sexuality and sexual health in the COVID-19 pandemic}

\author{
Ezgi Șahin®, ilkay Güngör Satılmıș²®
}

\section{öz}

$\mathrm{Bu}$ derlemenin amacı literatür doğrultusunda COVID-19 pandemisi nedeniyle öz izolasyon ya da sosyal uzaklaşma sürecinin, cinsellik ve cinsel sağlık üzerine etkisini açıklamaktır. Dünya Sağlık Örgütü (WHO) tarafından küresel bir salgın ilan edilen Coronavirus hastalığı 2019 (COVID-19), Şiddetli Akut Solunum Sendromu Coronavirus-2 (SARS$\mathrm{CoV}-2)$ olarak bilinen yeni bir koronavirüs tarafından ortaya çıkmıştır. Salgın süresince, bulaşma riskini azaltmak için insanlardan birbirlerine karşı aralarına sosyal mesafe koymaları beklenmektedir. Ancak sosyal mesafeden etkilenebilecek davranışlardan biri cinsel aktivitedir. Çünkü COVID-19, büyük solunum damlacıkları ve enfekte sekresyonlarla doğrudan temas yoluyla bulaşan bir solunum virüsü olup öpüşme ve fiziksel temasla geçme riski olan bir enfeksiyon hastalı̆̆ıdır. Bu risk nedeniyle de insanların birbirleriyle uzaklaștığı bu dönemde cinsel isteksizlikle birlikte cinsel aktivite sıklığında da azalma görülmektedir.

Anahtar Kelimeler: Covid-19, (SARS-CoV-2), cinsellik, cinsel akitivite, cinsel sağlık

\section{GiRiș}

Coronavirüs enfeksiyonu (COVID-19) 2019 yilının sonlarında Çin Wuhan'dan dünyaya yayılmıştır. Dünya Sağlık örgütü (WHO), 2020 Şubat'ta hastalığı COVID-19, etken virüsü "severe acute respiratory syndrome (Şiddetli Akut Solunum Sendromu Coronavirus-2 (SARS-CoV-2)) şeklinde tanımladı. ${ }^{[1,2]}$ Virüs damlacık ve kontamine yüzeylerden el, göz, burun mukozası ya da ağız yoluyla bulaşmakta olup, önemli morbidite ve sosyoekonomik etki ile birlikte ülke çapında kilitlenmeler ve sınır kapanmaları da dahil olmak üzere tüm kıtalarda sert tedbirler gerektirmiştir. SARS-CoV-2 virüsü asemptomatik bireylerden izole edilmiştir ve etkilenen hastalar semptomların kesilmesinden

'Iistanbul Arel Üniversitesi, Tıbbi Hizmetler ve Teknikler Bölümü, illk ve Acil Yardım Programı, Istanbul, Türkiye

2istanbul Üniversitesi - Cerrahpaşa, Florence Nightingale Hemşirelik Fakültesi, Kadın

Sağığı ve Hastalıkları Hemşireliği Anabilim Dalı, İstanbul, Türkiye

\section{Yazıșma Adresi/ Correspondence:}

Ezgi Şahin

İstanbul Arel Üniversitesi, Kemalpaşa Mahallesi Halkalı Caddesi Sefaköy-

Küçükçekmece İstanbul, Türkiye

Tel. $\quad$ +905316961737

E-mail: ezgishn90@gmail.com

Geliș/ Received: $\quad 12.06 .2020$

Kabul/ Accepted: $\quad 29.08 .2020$

\section{ABSTRACT}

The purpose of this review is to explain the effect of self-isolation or social withdrawal on sexuality and sexual health due to the COVID-19 pandemic in line with the literature. Coronavirus disease 2019 (COVID-19), which has been declared a global epidemic by the World Health Organization (WHO), has been introduced by a new coronavirus known as Severe Acute Respiratory Syndrome Coronavirus-2 (SARS$\mathrm{CoV}-2)$. During the epidemic, people are expected to distance themselves from each other to reduce the risk of transmission. However, one of the behaviors that can be affected by social distance is sexual activity. Because COVID-19 is a respiratory virus transmitted through direct contact with large respiratory droplets and infected secretions, an infectious disease at risk of kissing and physical contact. Due to this risk, the frequency of sexual activity decreases along with sexual reluctance during this period when people are diverging.

Keywords: Covid-19, (SARS-CoV-2), sexuality, sexual activity, sexual health

2 hafta sonra bulaşıcı olmaya devam etmektedir. ${ }^{[2]}$ Salgın süresince, bulaşma riskini azaltmak için insanlardan, insanlara karşı aralarına sosyal mesafe koymaları beklenmektedir. Ancak sosyal mesafeden etkilenebilecek davranışlardan biri cinsel aktivitedir. Sosyal mesafeden dolayı insanların birbirleriyle uzaklaştığı bu dönemde cinsel isteksizlikle birlikte cinsel aktivite sıklığında da azalma görülmektedir. Çünkü bir kişinin virüsü varsa, öpüşme ve fiziksel dokunuşla COVID-19'u geçme riski olduğu anlamına gelir. ${ }^{[2,3]}$ Virüsün vajinal sıvılarda olduğuna dair hiçbir kanıt yokken dışkıda bulunduğuna dair kanıtlar vardır, dolayısıyla oral ve anal seks yapmak da virüsün geçmesinin bir yolu olabilir. Cinselliğin sağlıklı yaşanabilmesi için cinsel yakınlığın bireyin özgür seçimlerine dayalı, hiçbir zorlama olmadan, mutlu ve zarar görmeden yaşayacağı bir yakınlık olması gerekmektedir. ${ }^{[4,5]} \mathrm{Bu}$ nedenle bu süreçte COVID-19 potansiyel zararlı sonuçlarını azaltabilmek adına günümüzde önerilen en güvenli cinsel aktivite ise kendi kendine (solo) veya uzaktan yapılan aktivitedir. New York Şehri Sağlık ve Zihinsel Hijyen Departmanı (The NYC Department of Health and Mental Hygiene) da, daha güvenli cinsel yaşam için resmi kılavuzunu yayınlayarak en güvenli cinsellik uygulamasının mastürbasyon olduğunu önermiştir. ${ }^{[4,5]} \mathrm{Bu}$ 
derlemenin amacı literatür doğrultusunda COVID-19 öz izolasyonu/sosyal uzaklaşma sürecinin, cinsellik ve cinsel sağlık üzerine etkisini açıklamaktır.

\section{COVID-19 VE CINSEL SAĞLIK}

Mart 2020'de Dünya Sağlık Örgütü (WHO) tarafından küresel bir salgın ilan edilen Coronavirus hastalığ 2019 (COVID-19), Şiddetli Akut Solunum Sendromu Coronavirus-2 (SARS-CoV-2) olarak bilinen yeni bir koronavirüs tarafından ortaya çıkmıştır. COVID-19, büyük solunum damlacıkları ve enfekte sekresyonlarla doğrudan temas yoluyla bulaşan bir solunum virüsüdür. ${ }^{[3]}$

COVID-19 salgın süresince, bulaşma riskini azaltmak için insanlardan çevresinde ki herkese karşı sosyal mesafe koymaları beklenmektedir. Ancak bu sosyal mesafe ve temas kısıtlamaları hem kişilerarası hem de partner ilişkilerini etkilediği için insanların cinsel aktivitelerini de olumsuz yönde etkileyecektir. ${ }^{[4]}$ Cinsellik davranışlar, tutumlar, kimlik, yönelim, inançlar ve faaliyetleri içeren çok sayıda olguyu kapsar ve özellikle cinsel aktivite, vajinal, anal, oral seks ve karşılıklı mastürbasyon da dahil olmak üzere çok sayıda eylemi kapsayabilir. ${ }^{[3-5]}$ Cinsel sağlık ise, sadece hastalık, fonksiyon bozukluğu veya sakatlığın olmaması değil, cinselliğe ilişkin fiziksel, duygusal, zihinsel ve sosyal olarak sağlıklı olma durumu gibi geniş kavramları kapsamaktadır. [5] Aynı zamanda cinsel sağlık, cinsellik ve cinsel ilişkilere yönelik hem olumlu ve saygılı bir yaklaşım, hem de zorlama, ayrımcılık ve şiddetten arınmış keyifli ve güvenli cinsel deneyimlere sahip olmayı gerektirir. ${ }^{[5]}$ Mevcut kanıtlara dayanarak, COVID-19 hastalığına neden olan koronavirüs, vajinal veya anal ilişkiden geçmez ancak koronavirüs enfekte olmuş bir kişinin tükürüğü de dahil olmak üzere, burun ve ağızdan damlacıklar ile temas yoluyla, ortaya çıkabilir. Bu durum bir kişinin virüsü varsa, öpüşme ve fiziksel dokunuşla COVID-19'u geçme riski olduğu anlamına gelir. ${ }^{[3,5]}$ Yapılan birkaç çalışma, COVID-19'dan etkilenen hastaların dışkısında viral RNA'nın varlığını göstermiştir, bu da oral fekal yoldan viral bulaşma olasılığını düşündürmektedir, dolayısıyla oral ve anal seks yapmak virüsün geçmesinin bir yolu olabilir. Ayrıca test sonuçları negatif olduktan sonra bile fekal testlerin pozitif olmaya devam ettiğine dair kanıtlar vardır. ${ }^{[6-9]}$ Virüsün vajinal sıvılarda olduğuna yönelik hiçbir kanıt yoktur. Ancak yapılan bir kohort çalışmasında akut enfeksiyon evresinde olan hastaların semen testi sonuçlarında SARS-CoV-2 için pozitif sonuca rastlanıldığı saptanmıştır. Ancak bu virüsün meni yoluyla yani cinsel yolla bulaşabileceği hakkında yeterince bilgi yoktur. ${ }^{[10]}$ Önceki koronavirüs salgını verilerinde de erkek cinselliğinin olası etkileri hakkında net bilgi bulunmamaktadır. Ancak testiküler örnekler üzerinde yapılan bir çalışmada, SARS korona virüsünün üreme sistemi üzerinde önemli bir etkisi olduğunu göstermiştir. ${ }^{[11]}$ Ayrıca SARS nedeniyle ölen 6 hastanın testisinde ki patolojik varyasyonlar incelenmiş ve SARS' ${ }_{1}$ testislerde orşite neden olduğu, seminifer tübüllerde çok az veya hiç spermatozoa bulunmayan germ hücrelerinde yaygın hasar gösterdiğ bulunmuştur. ${ }^{[11]}$ SARS-CoV-2'den iyileşen 34 Çinli hasta üzerinde yapılan bir çalışmada ise, 6 hasta aktif hastalık sırasında skrotal rahatsızlık bildirmiş, ancak kapsamlı bir genitoüriner muayene yapılmamıştır. ${ }^{[12]}$

ACE2, anjiyotensin dönüştürücü enzimin (ACE) bilinen ilk insan homologudur. ACE ekspresyonu çoğunlukla her yerde bulunurken, ACE2 transkriptleri sadece kalp, böbrek ve testiste bulunur. ${ }^{[11]}$ Son zamanlarda, yetişkin insan testisindeki ACE2 ekspresyonunun tek hücreli transkriptom sekanslaması ile analizi, ACE2 ekspresyonunun esas olarak insan testisindeki Leydig ve Sertoli hücreleri ile sınırlı olduğunu ortaya koymuştur. ${ }^{[11]}$ Ayrıca, Gen Set Zenginleştirme Analizi (GSEA) kullanarak ACE2-pozitif spermatogoninin, viral üreme ve iletim ile ilişkili daha fazla sayıda gen ve ACE2-negatif spermatogoniye kiyasla nispeten daha az sayıda gen sergilediği belirtilmektedir. Benzer şekilde, ACE2-pozitif Leydig ve Sertoli hücreleri, hücre-hücre birleşimi ile ilgili daha fazla sayıda gen, üreme ile ilişkili daha az sayıda gen gösterdi. ${ }^{[11]}$ Ayrıca yaptıkları bu çalışma ile testisin, spermatojenik başarısızlığa neden olabilecek SARS - CoV-2 enfeksiyonuna karşı savunmasız yüksek riskli bir organ olduğu sonucuna varmışlardır. [11] Yapılan diğer çalışmada da son zamanlarda, yetişkin insan testisinin tek hücreli RNA - Sıralaması, ACE2'nin hem virüs hem de somatik hücreler tarafindan eksprese edildiğini göstermiştir. Bu durum da ACE2'nin aşırı aktifleştirilmesinin spermatogenezi etkileyebileceğini düşündürmektedir. ${ }^{[11]}$

SARS-CoV-2'nin gelecekteki çalışmalarda cinsel yolla bulaşabileceği kanıtlanabilirse, özellikle iyileşen hastaların sperminde SARS-CoV-2'nin tespit edildiği göz önüne alındığında, sperm iletimin önlenmesinin kritik bir parçası olabilir. Bu nedenle prezervatif gibi bariyer kullanımı bu hastalar için koruyucu araç olarak düşünülebilir. ${ }^{[10,12,13]}$ COVID-19 potansiyel zararlı sonuçlarını azaltabilmek adına günümüzde önerilen en güvenli cinsel aktivite kendi kendine (solo) veya uzaktan yapılan aktivitedir. Bu süreçte yalnız kalındığında el yardım ile ya da cinsel oyuncaklar kullanarak mastürbasyon yapmak hem tatmin edici hem de güvenli olabilir. Önerilen diğer bir seçenek ise fiziksel olarak kimse olmadan günümüz teknolojisinin sunduğu görüntülü sohbetler, popüler flört uygulamaları ve cinsel içerikli mesajlaşma gibi farklı türde uygulamaların kullanılmasıdır. ${ }^{[4,9,10]}$ Bir sonraki en güvenli seçenek ise, düzenli 
birlikte yaşanılan partnerle yapılan cinsel aktivitedir. Ancak partnerin diğer insanlarla cinsellik yaşaması COVID-19 olma riskini artırır. Eğer partnerlerden biri; kuru kalıcı bir öksürük, yüksek ateş veya solunum zorluğu gibi COVID-19 semptomları sergiliyorsa, virüsün yayılmasını durdurmak için tüm fiziksel temas sınırlandırılmalıdır. Bu durum, öpüşme ve sarılma gibi fiziksel yakınlıklardan kaçınmanın yanı sıra anal, vajinal veya oral seksten kaçınmak anlamına da gelmektedir. ${ }^{[3,5]}$

Sosyal mesafeden dolayı insanların birbirleriyle uzaklaştı$\breve{g}_{1}$ bu dönemde cinsel isteksizlikle birlikte cinsel aktivite sıklığında da azalma görülmektedir. İngiltere de 868 kişi ile yapılan bir çalışmada katılımcıların \%60,1'inin kendi kendine izolasyon/sosyal uzaklaşma sırasında cinsel olarak aktif olmadığı bildirilmiştir. Cinsel aktivite sayısı erkeklerde kadınlara göre anlamlı olarak daha yüksek olduğu belirtilmiştir $(\mathrm{P}=0,002)$. Cinsel aktivite ile anlamlı olarak ilişkili değişkenler ise erkek ve genç yaşta olmak, evli veya aile ile yaşamak, alkol tüketme ve izolasyon günlerinin artmasıdır $(\mathrm{p}<0,001) .{ }^{[4]} \mathrm{Bu}$ bulgular pandemi olmayan zamanlarda mevcut literatüre karşıllık gelmektedir. ${ }^{[10,14-17]} \mathrm{Bu}$ çalışmada aynı zamanda kendi kendine izolasyon/sosyal uzaklaşmadaki gün sayısının da cinsel aktivite ile ilişkili olduğu belirtilmektedir. Bu durum, cinsel aktivitenin, izolasyon günlerinin uzamasıla stres ve endişeyi hafifletmek veya can sıkıntısının üstesinden gelmek için bir araç olarak kullanılması gerçeğiyle açıklanabilir. Ancak bu süreçte cinsel yolla bulaşan hastalıkları ve istenmeyen gebeliği önlemek için prezervatif gibi bariyer kullanmanın kaçınılmaz bir durumdur. ${ }^{[4,5]}$

Çin'de yapılan bir çalışmada da katılımcıların \%25'i cinsel istekte azalma yaşadığı, \%44'ünün cinsel partner sayısında azalma olduğu ve erkeklerin kadınlara göre cinsel partner sayısında azalmanın daha düşük olduğu (\%53'e karşı \%30) belirtilmiştir. Ayrıca erkeklerin \%32'si ve kadınların \%39'u cinsel tatminde de azalma yaşadığını belirterek, riskli cinsel deneyimler öyküsü olan katılımcıların çoğu da COVID-19 salgını sonrasında riskli cinsel davranış eylemlerinin de azaldığını ifade etmişlerdir. ${ }^{[18]}$

\section{Covid-19'Un CINSELLiĞE ILLȘKKIN PSIKOLOJIK ETKILERI}

COVID-19 salgını Dünyadaki yaşam biçimini kökten değiştirdi. Pandemi durumu, nüfusu evde kalmaya zorlayıp hem kişilerarası hem de partner ilişkilerini kökten değiştirmektedir. Bu değişiklikler aynı zamanda insanları, zihinlerinin ve bedenlerinin yeni sürece alışması için zaman bırakmadan çok kısa sürede etkilemiştir. Dünyadaki, hastalık ve ölüm imgelerine sürekli maruz kalmakla birlikte, her bireyin duygusal durumu da olumsuz bir şekilde etkilenmektedir. Literatürde, çeşitli çalışmalar genel popülasyonun ağır akut solunum sendromu salgınına psikososyal tepkilerini incelemiş olup, inceleme sonucunda psikolojik tepkilerin daha çok anksiyete, korku, depresyon, öfke, suçluluk, ağrı ve kayıp, travma sonrası stres bozukluğu ve damgalanma olduğu belirtilmektedir. ${ }^{[19,23]}$ Bununla birlikte günlük rutinin değişmesi, herkesin özgürlüğünün ve bağımsızlığının sınırlandırılması, evden çalışma, sosyal uzaklaşma, evde çocukların varlığı, enfeksiyon korkusu ve başkalarıyla fiziksel olarak tanışamamak çoğu insanın cinsel alışkanlıklarını da değiştirmektedir. Psikolojik, sosyal ve biyolojik değișkenlerin etkileșimi içinde șekillenen cinsellik de, bu süreçten olumsuz olarak etkilenmektedir. [4,20] Çünkü SARS-CoV-2'nin cinsel yolla bulaşma ile ilgisi tam olarak tespit edilememiş olup bu durum açıklığa kavuşana kadar SARS-CoV-2'nin potansiyel olarak bulaşıcı olduğu düşünülmektedir. Bu süreçten dolayı da cinsel aktivite sıklığında azalma görülmektedir. ${ }^{[5,10]}$ Cinsel aktivitenin azalmasında psikolojik faktörler ve belirli ruh hali durumları da rol oynamaktadır. Ayrıca yaşanan bu psikolojik sorunların cinsel işlev bozukluğuna da yol açabileceği belirtilmektedir. Yapılan çalışmalarda da depresyon ve anksiyete çoğunlukla düşük düzeyde arzu ile ilişkilendirilmiştir. ${ }^{[21,22]}$ Bununla birlikte evlilik dışı cinsel birliktelikler ve riskli cinsel deneyim öyküsü olan çoğu kişinin riskli cinsel davranışlarında hızlı bir azalma olduğu görülmektedir. Bunun nedeni, ülkelerin getirdiği yasal kısıtlamalar, yeni cinsel partner bulamama, cinsel birliktelik için uygun bir yer bulamama ve insanların bu dönemde kayg1, korku ve sıkıntı gibi çok fazla psikolojik stres yaşamaları olabilir. ${ }^{[18,20,23,25]}$ Daha önceki salgınlardan ötürü de alınan karantina önlemlerinin; depresif belirtiler, anksiyete, öfke, stres, travma sonrası stres bozukluğu, sosyal izolasyon, yalnızlık ve damgalanma gibi olumsuz psikososyal sonuçlarla tutar1 bir şekilde ilişkili olduğu bulunmuştur. ${ }^{[18]}$ Sonuç olarak Covid-19'un hem cinsel yolla bulaşma korkusundan hem de sürecin getirdiği psikolojik sorunlardan dolayı cinsel aktivitenin azaldığı yadsınamaz bir gerçektir. Ancak bazı kişiler için ise, cinsel aktiviteden tamamen uzak durmak ulaşılabilir bir hedef değildir. Bu durumlarda, kendi kendine ya da karantinada kaldıkları kişilerle cinsel birliktelik en güvenli yaklaşımdır. ${ }^{[24]}$

\section{COVID 19'DA GÜVENLI CINSELLIK ÖNERILERI}

New York Şehri Sağlık ve Zihinsel Hijyen Departmanı (The NYC Department of Health and Mental Hygiene) da Covıd-19 zamanında güvenli cinsellik yaşamak için bazı önerilerde bulunmuştur. ${ }^{[26]}$ 
- COVID-19’un nasıl yayıldığını öğrenin

- Size "yakın” insanlarla cinsellik yaşayın. Sizin en güvenli seks partneriniz kendinizsiniz. Mastürbasyon, COVID19'u yaymaz, sadece dikkat etmeniz gereken ellerinizi (ve herhangi bir cinsel oyuncaklar) cinsel ilişkiden önce ve sonra önce ve sonra en az 20 saniye sabun ve suyla yıkamalısınız.

- Bir sonraki en güvenli partner, birlikte yaşadığınız kişidir. Cinsel aktivite dâhil olmak üzere sadece yakın çevre ile temasta bulunmak COVID-19'un yayılmasını önlemeye yardimci olur.

- Haneniz dışındaki herhangi biriyle cinsel aktivite dahil olmak üzere yakın temastan kaçınmalısınız. Başkalarıyla da cinsel birliktelik yaşarsanız, mümkün olduğunca az partneriniz olsun.

- Genellikle seks partnerinizle çevrimiçi olarak tanışıyoranız veya seks işçisi olarak geçiminizi sağlıyorsanız, yüz yüze görüşmelere ara vermeyi düşünün. Video aracıl1ğıyla buluşmalar, cinsel içerikli mesajlaşma veya sohbet odaları sizin için seçenek olabilir.

- Ev dışında biriyle öpüşmekten kaçının. Öpüşme yoluyla COVID-19 hızlıca bulaşır

- Tükürük veya dışkı ile teması azaltmak için oral veya anal seks sırasında prezervatif veya bariyerler kullanın.

- Anüs çevresini oral yolla uyarma içeren (rimming) cinsel aktivitelerden kaçının.

- Hem cinsel ilişkiden önce hem de ilişkiden sonra duş alın, ellerinizi ve vücudunuzu sabun ve suyla iyice yıkayın.

- Cinsel oyuncaklar kullaniyorsanız, bunları sabun ve suyla iyice yıkayın ve kimseyle paylaşmayın.

- Siz veya eşiniz COVID-19'a sahipse, cinsel birliktelikten ve özellikle öpüşmekten kaçının.

- Kendinizi iyi hissetmezseniz, belirtilerinizi izleyin. Ateş, öksürük, boğaz ağrısı veya nefes darlığı gibi COVID-19 belirtileriniz olursa, sağlık uzmanınıza başvurun.

- Siz veya eşiniz COVID-19'a yol açabilecek daha ciddi bir duruma sahipse cinsel birlikteliğe ara verin.

\section{SONUÇ}

Pandemi öncesi normal zamanlarda, insanların yoğun yaşamlarından ötürü eşiyle ya da partneriyle vakit geçirmek için kısıtlı zamanları olabilir. COVID-19'un getirmiş olduğu izolasyon süreci günün yarısını bazen de tamamını alan işe gidip gelmek gibi günlük rutinleri bozmuş olabilir, ancak bu izolasyon süreci kişilerin partneriyle birlikte daha çok zaman geçirmesine dolayısıyla da cinsel aktiviteyi daha düzenli yaşamalarına imkan verebilir gibi görünse de salgın sürecinde alınan karantina önlemlerinin; insanlarda anksiyete, öfke, stres, sosyal izolasyon, yalnızlık gibi psikolojik sorunların cinsel ilişkileri olumsuz etkilediğini söylemek mümkündür. Genel olarak, yapılan çalışmalarda COVID-19 salgını sürecinde erkeklerin ve kadınların hem cinsel faaliyetlerinin hem de cinsel memnuniyetinin azaldığı belirtilmektedir. Ancak korku veya kaygı nedeniyle cinsel işlev bozukluğunun artması konusunda psikolojik, sosyal ve biyolojik faktörler de araştırılmalıdır, çünkü insan cinselliği birçok durumdan etkilenen karmaşık bir olgudur. Sonuç olarak COVID-19'un etkisi insanların cinsel yaşamında da çok önemli olacağı ve önümüzdeki aylarda veya yıllarda tüm seviyelerdeki ilişkilerde bazı değişikliklere neden olacağı düşünülmektedir.

\section{Hakem Değerlendirmesi \\ Dış bağımsız \\ Çıkar Çatışması \\ Yazarlar çıkar ilişkisi olmadığını beyan etmişlerdir. \\ Finansal Destek \\ Herhangi bir mali destek alınmamıştır.}

\section{Peer-review}

Externally peer-reviewed.

Conflict of Interest

No conflict of interest was declared by the authors.

Financial Disclosure

No financial disclosure was received.

\section{KAYNAKLAR}

1. Public Health England. COVID-19: epidemiology, virology and clinical features 2020. https://www.gov.uk/government/ publications/wuhan-novel-coronavirus-background-information/ wuhan-novel-coronavirus-epidemiology-virology-and-clinicalfeatures

2. National Health Service. Advice for everyone - Coronavirus (COVID-19) 2020. https://www.nhs.uk/conditions/coronaviruscovid-19/

3. World Health Organisation. Coronavirus disease (COVID-19) pandemic. https://www.who.int/emergencies/diseases/novelcoronavirus-2019

4. Jacob L, Smith L, Butler L, Barnett Y, Grabovac I, McDermott D, et al. Challenges in the Practice of Sexual Medicine in the Time of COVID-19 in the United Kingdom. J Sex Med 2020. [CrossRef]

5. World Health Organisation. Sexual and reproductive health and research including the Special Programme HRP, 2020. https://www. who.int/reproductivehealth/topics/sexual_health/sh_definitions/en/

6. Nouri-Vaskeh M, Alizadeh L. Fecal transmission in COVID-19: A potential shedding route. J Med Virol 2020;92:1731-2. [CrossRef]

7. Zhang W, Du R-H, Li B, Zheng X-S, Yang X-L, Hu B, et al. Molecular and serological investigation of 2019-nCoV infected patients: Implications of multiple shedding routes. Emerg Microbes Infect 2020;9:386-9. [CrossRef]

8. Tian Y, Rong L, Nian W, He Y. Review article: Gastrointestinal features in COVID-19 and the possibility of faecal transmission. Aliment Pharmacol Ther 2020;51:843-51. [CrossRef]

9. Avert, global information and education on HIV and AIDS. Sex and Coronavirus (COVID-19). https://www.avert.org/printpdf/ node/ 4554 
10. Li D, Jin M, Bao P, Zhao W, Zhang S. Clinical Characteristics and Results of Semen Tests Among Men With Coronavirus Disease 2019. 2020;3:e208292. [CrossRef]

11. Donoghue M, Hsieh F, Baronas E, Godbout K, Gosselin M, Stagliano N, et al. A novel angiotensin-converting enzyme-related carboxypeptidase (ACE2) converts angiotensin I to angiotensin 1-9. Circulation Res 2000;87:1-9. [CrossRef]

12. Pan F, Xiao X, Guo J, Song Y, Li H, Patel DP, et al. No evidence of SARS-CoV-2 in semen of males recovering from COVID-19. Fertil Steril 2020;113:1135-9. [CrossRef]

13. Wang $\mathrm{Z}, \mathrm{Xu} \mathrm{X}$. scRNA-seq profiling of human testes reveals the presence of the ACE2 receptor, A target for SARS-CoV-2 infection in spermatogonia, leydig and sertoli cells. Cells 2020;9:920. [CrossRef]

14. ASHA, American Sexual Health Association. Sex and COVID-19. Understand the risks of sex and intimate contact in the time of COVID-19. http://www.ashasexualhealth.org/sex-in-the-time-ofcovid-19/

15. Shen Q, Xiao X, Aierken A, Liao M, Hua J. The ACE2 Expression in Sertoli cells and Germ cells may cause male reproductive disorder after SARS-CoV-2 Infection. OSF Preprints 2020;24. [CrossRef]

16. Smith L, Yang L, Veronese N, Soysal P, Stubbs B, Jackson SE. Sexual Activity is Associated with Greater Enjoyment of Life in Older Adults. Sex Med 2019;7:11-8. [CrossRef]

17. Lee DM, Nazroo J, O’Connor DB, Blake M, Pendleton N. Sexual Health and Well-being Among Older Men and Women in England: Findings from the English Longitudinal Study of Ageing. Arch Sex Behav 2016;45:133-44. [CrossRef]

18. Grabovac I, Smith L, Yang L, Soysal P, Veronese N, Işsı AT, et al. The relationship between chronic diseases and number of sexual partners: an exploratory analysis. BMJ Sex Reprod Health 2020;46:100-7. [CrossRef]
19. Grabovac I, Koyanagi A, Yang L, López-Sánchez GF, McDermott D, Soysal P, et al. Prospective associations between alcohol use, binge drinking and sexual activity in older adults: the English Longitudinal Study of Ageing. Psychol Sex 2019:1-9. [CrossRef]

20. Lei L, Huang X, Zhang S, Yang J, Yang L, Xu M. Comparison of prevalence and associated factors of anxiety and depression among people affected by versus people unaffected by quarantine during the COVID-19 epidemic in southwestern China. Med Sci Monit 2020;26:e924609. [CrossRef]

21. Chew QH, Wei KC, Vasoo S, Chua HC, Sim K. Narrative synthesis of psychological and coping responses towards emerging infectious disease outbreaks in the general population: practical considerations for the COVID-19 pandemic. Singapore Med J 2020;61:350-6. [CrossRef]

22. Brooks SK, Webster RK, Smith LE, Woodland L, Wessely S, Greenberg N, Rubin J. The psychological impact of quarantine and how to reduce it: rapid review of the evidence. Lancet 2020;395:912-20. [CrossRef]

23. Li W, Li G, Xin C, Wang Y, Yang S. Challenges in the Practice of Sexual Medicine in the Time of COVID-19 in China. J Sex Med 2020;17:1225-8. [CrossRef]

24. Mieras M. Seksuele lust, de hersenen en ons lichaamsbewustzijn [Sexual desire, the brain and our interoceptive consciousness]. Ned Tijdschr Geneeskd 2018;162:D2758. https://pubmed.ncbi.nlm. nih.gov/30040333/

25. Nimbi FM, Tripodi F, Rossi R, Simonelli C. Expanding the Analysis of Psychosocial Factors of Sexual Desire in Men. J Sex Med 2018;15:230-44. [CrossRef]

26. NYC Health. Promoting and Protecting the City's Health. Coronavirus Disease 2019 (COVID-19). https://www1.nyc.gov/ site/doh/covid/covid-19-main.page 